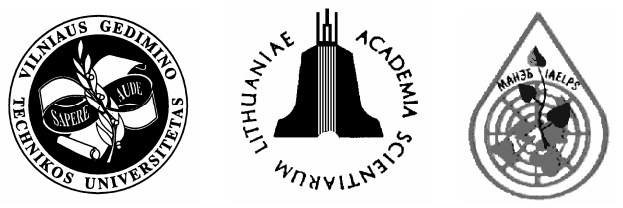

\title{
COMPOSITION OF FLAMMABLE MATERIAL AND AIR MIXTURES CORRESPONDING TO MAXIMUM FLAME PROPAGATION RATE
}

\author{
Algimantas Kazragis, Albinas Gailius \\ Dept of Chemistry and Bioengineering, Vilnius Gediminas Technical University, \\ Saulètekio al. 11, LT-10223 Vilnius, Lithuania. \\ E-mail:chemkat@fm.vtu.lt
}

Submitted 5 Jan 2006; accepted 15 Mar 2006

\begin{abstract}
Relationship between the important fire protection indices - flammable gaseous materials (or vapours arising from liquid flammable materials during a fire) concentrations in gas-air mixtures at maximum flame diffusion rate - and stoichiometric oxygen molecule number in combustion reaction equation were investigated.

The obtained equation combining the above mentioned factors were used to calculate especially dangerous flammable organic material concentrations in combustible mixtures. The obtained data will allow undertaking preventive measures and evaluating various stored materials which are fire hazards at construction and military sites.
\end{abstract}

Keywords: combustion reactions, flammable material concentrations, fire spreading rate.

\section{Introduction}

A large influence on the Earth's climate is determined by the intensification of the greenhouse effect in recent years. This is caused by increase in $\mathrm{CO}_{2}$ amount in the Earth's atmosphere. $\mathrm{CO}_{2}$ molecules absorb irretrievable part of the Sun's energy reaching the Earth's surface. As a result the Earth's temperature is slowly but surely increasing.

One of the $\mathrm{CO}_{2}$ paths into the Earth's atmosphere is through the combustion process of organics.

Combustion is a complex physico-chemical process - a spontaneous chemical oxidation-reduction reaction, during which redistribution of reacting material atom valent electrons occurs. Heat and light as a flame is evolved during combustion [1-3].

Flammable materials and oxidators take part in the combustion process.

Various flammable materials are used in industry, technics and domestic fields. In our opinion the most important ones can be divided as follows:

1) elementary substances - metals (sodium, potassium, magnesium, aluminium) and non-metals (hydrogen, carbon, phosphorus, sulphur);

2) inorganic materials - hydrides (borum, nitrogen, silicon, phosphorus, sulphur); lower oxidation degree oxides (carbon monoxide); sulfides, nitrides, phosphides;

3) organic materials - hydrocarbons (alkanes - methane, ethane, propane, butane, octane, etc); alkene (ethylene and others), aromatic hydrocarbons (benzene, toluene, ksilene, styrene, etc); alcohols (methanol, ethanol, butanol, etc); ethers (dimethyl as well as diethyl ethers); aldehydes (formaldehyde, acetaldehyde, etc); ketones (acetone, etc); carboxy acids (acetic acid, etc); esters (ethyl acetate, etc); nitro compounds (nitrobenzene, etc); amines (ethylamine, etc);

4) natural organic combustible materials (crude oil, coal, lignite or brown coal, combustible shale, natural gas) as well as its refining products (gasoline, kerosene, diesel fuel, etc);

5) macromolecular organic materials - plastics and its articles, natural cellulose raw materials and its reprocessed products as well as production waste (wood, agricultural production products, peat, cultural and noncultural vegetation, forests).

Organic materials, as a matter of fact, can be burnt, e $g$ industrial fuels, also fuels at factories, warehouses, auto parks and other organic assortments.

Oxidizers, like air, oxygen, ozone, hydrogen peroxide, sodium and other metal peroxides, halogens (fluorine, chlorine), nitric acid and its salts - nitrates (saltpetre), chlorates as well as perchlorates and other materials can be used.

Combustion can be homogeneous (natural gas combustion in air), heterogeneous (heavy oil droplets in air) and combustion of explosives.

A flame is a very important combustion process result. The flame temperature and brightness depends on the combustible materials and oxidator composition as well as its state. For example, the combustion temperature of hydrogen and air mixture is $1900{ }^{\circ} \mathrm{C}$, in the case of acetylene-oxygen mixture it will reach $3000^{\circ} \mathrm{C}$, while for a cyanacetylene-ozone mixture - even $6000{ }^{\circ} \mathrm{C}$ [1].

The flame can propagate from its source at a certain rate. The flame propagation is connected with heat transmission due to thermal conductivity, and is called natural 
propagation, while its corresponding flame propagation rate-normal flame propagation rate, its dimension is $\mathrm{m} / \mathrm{s}$. This indice depends on combustible material composition, combustible mixture composition, pressure, initial combustible mixture temperature and presence of admixtures.

Normal flame propagation rate (in $\mathrm{m} / \mathrm{s}$ ) differ widely for various combustible materials. For example, when paper burns in a roll, it is even to 0,3 ; for textile articles $0,3-0,4$; for synthetic rubber $-0,4$; for wooden constructions - 1-4; for ethanol 8-20; for acetone -32 ; for hexane -32 ; for pentane -35 ; for methane -36 ; for diethyl ether, benzene -38 ; for propylene -43 ; for carbon monoxide -46 ; for carbon disulfide -48 ; for ethylene 63'; for acetylene - 120; for hydrogen - 225 [1].

The combustion temperature during a fire varies: in dwelling quarters and public premises it is (800-900 ${ }^{\circ} \mathrm{C}$ ); in quaters where fuel burns $\left(1000-1400{ }^{\circ} \mathrm{C}\right)$; when magnesium or termite burns it reaches $\left(2000-3000{ }^{\circ} \mathrm{C}\right)$.

Fumes from fires contain toxic gases - charcoal fumes, nitrogen oxide, phosgene, hydrogen cyanide [2].

As it is well known, living organisms are alive while they inhale oxygen from the air and when it circulates in the organism. Oxygen is transported and distributed through the organism by hemoglobin $\mathrm{C}_{758} \mathrm{H}_{1203} \mathrm{~N}_{195} \mathrm{O}_{218} \mathrm{FeS}_{3}$ (abbreviation - hb) in the blood. This is a two-way process:

$$
\mathrm{hb}+\mathrm{O}_{2} \leftrightarrow \mathrm{hb} \cdot \mathrm{O}_{2} .
$$

If charcoal gas $\mathrm{CO}$ is present in the inhaled air alongside $\mathrm{O}_{2}$, it can be deathly bonded with the hb molecule:

$$
\mathrm{hb}+\mathrm{CO} \leftrightarrow \mathrm{hb} \cdot \mathrm{CO} .
$$

As a result, the organism can die.

The $\mathrm{CO}$ amount in combustion products depends on the amount of $\mathrm{O}_{2}$ present in the air: if there is a small amount of $\mathrm{O}_{2}$ in the air, less full combustion products are formed $-\mathrm{CO}_{2}$, and in place of it deathly dangerous $\mathrm{CO}$ arises.

Not only does nature and buildings suffer during fires, but also people who work at fire sites.

So, one of the most important flammable gases as well as easily vaporized fluid vapour mixtures with air combustion characteristics is the maximum flame propagation rate of a fire. The knowledge of this value during the storage, transportation and usage of various flammable organic compounds, thinners, lacquers and other products containing organics can help in ecological and life important safety aspects.

Material and air mixture concentration of various organic flammable materials, at ambient temperatures or transformation at higher temperatures at maximum normal flame propagation rate values calculations were performed with that aim. Investigation is based on references [4-15].

The investigation results given below have an environmental and vital human safety character.

\section{Investigation results and discussion}

\subsection{Deduction of equations describing composition of combustible material and air mixture at maximum flame propagation rate}

The following abbreviations are used in the text: $V_{\%}$-combustible material volume concentration in a mixture with air, $\% ; v_{1}, \mathrm{~cm} / \mathrm{s}$ - maximum normal flame propagation rate; $\mathrm{O}_{2}$ - oxygen.

The equation which is used to calculate the $V_{\%}$ value, when combustion reaches $v_{l}$, is obtained by analysis of a combustible material, combustion reaction, e g octane $\mathrm{C}_{8} \mathrm{H}_{18}$ - one of the constituents of gasoline:

$$
\mathrm{C}_{8} \mathrm{H}_{18}+12,5 \mathrm{O}_{2}=8 \mathrm{CO}_{2}+9 \mathrm{H}_{2} \mathrm{O} \text {. }
$$

As we can see from the equation, combustion of $1 l$ of octane requires $12,5 l$ of oxygen. Because the amount of oxygen in the air is only $20,947 \%$ of the air volume (or 0,21 parts), then if we do not take into account the changes in gaseous volume with increase in temperature, we obtain the following equation:

$$
V_{\%}=100 /\left(1+4,76 n_{O_{2}}\right), \%
$$

where 4,76-coefficient, which is the inverse of oxygen content in air by parts and even to 0,$21 ; n_{\mathrm{O}_{2}}-$ stoichiometric coefficient of $\mathrm{O}_{2}$ value in the equation.

According to equation (2), we find $V_{\%}$ values for a number of characteristic combustible organic materials (materials are arranged with an increase in $V_{\%}$ nomenator shows the $V_{\%}$ values found by (2), the denumeratordetermined from experimental curves [1]). The investigated group of materials is made up of the most important representatives of organic compounds from the practical usage point of view:

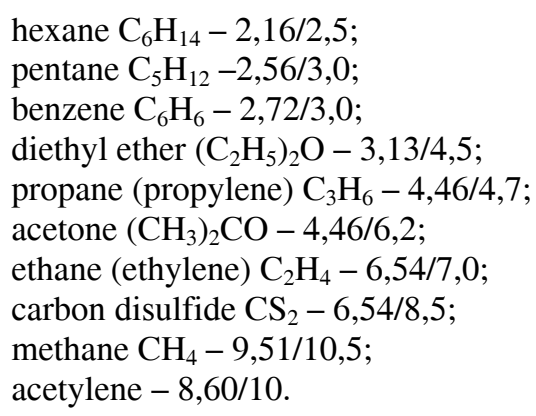

Correlation between the values found experimentally (from [1]) - $V_{\%(\exp )}$ and values obtained from equation (2) $-V_{\%(2)}$ are shown in Fig 1.

As it can be seen from Fig 1, connection between experimental (actual) $V_{\%}$ values and calculated values can be expressed by the following equations:

1 ) in the case of $\mathrm{C}-\mathrm{H}$ compounds -

$$
V_{\%}=1,11 / V_{\%(2)}, \%
$$

or when $V_{\%(2)}$ value from equation (2) is used -

$$
V_{\%}=111 /\left(1+4,76 n_{O_{2}}\right), \% \text {; }
$$




$$
\begin{aligned}
& \text { 2) in the case of } \mathrm{C}-\mathrm{O}-\mathrm{H} \text { compounds - } \\
& \qquad V_{\%}=1,11 V_{\%(2)}+1,2, \%,
\end{aligned}
$$

or when $V_{\%(2)}$ value from equation (2) is used -

$$
V_{\%}=111 /\left(1+4,76 n_{O_{2}}\right)+1,2, \% \text {, }
$$

where 111 - coefficient obtained by multiplying the equation (2) value 1,11 by $100 \%$, which takes into account the influence of the temperature coefficient with increase in reaction temperature; 1,2 - coefficient, which takes into account the presence of $\mathrm{O}$ and $\mathrm{S}$ atoms in the combustible material composition and influence on the increase in the amount of materials in a combustible mixture.

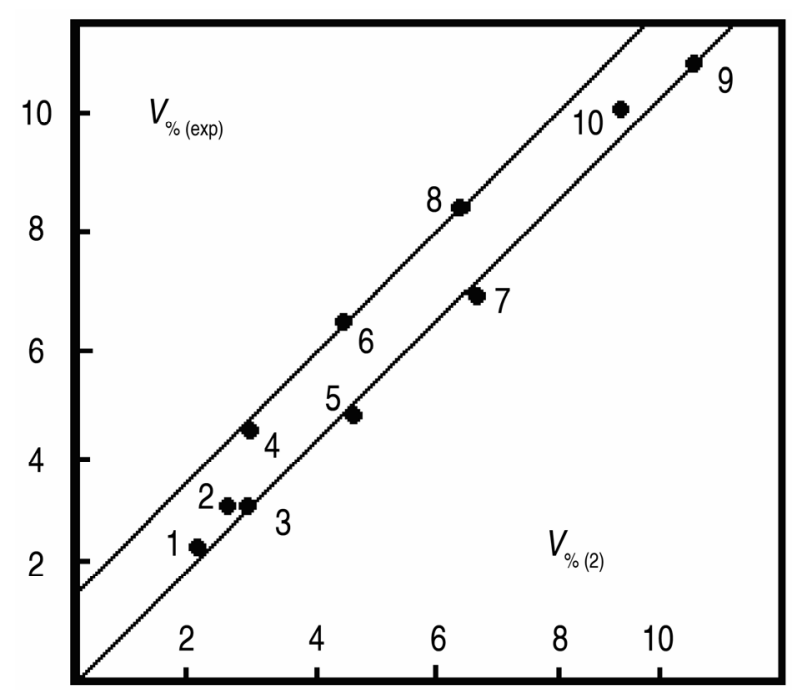

Fig 1. Correlation between $V_{\%}$ values, found experimentally (from [1]) $-V_{\%(\exp )}$ and values obtained from equation (2) $-V_{\%(2)}$. Materials: $1-\mathrm{C}_{6} \mathrm{H}_{14}, 2-\mathrm{C}_{5} \mathrm{H}_{12}, 3-\mathrm{C}_{6} \mathrm{H}_{6}$, $4-\left(\mathrm{C}_{2} \mathrm{H}_{5}\right)_{2} \mathrm{O}, 5-\mathrm{C}_{3} \mathrm{H}_{6}, \quad 6-\left(\mathrm{CH}_{3}\right)_{2} \mathrm{CO}, \quad 7-\mathrm{C}_{2} \mathrm{H}_{4}$, $8-\mathrm{CS}_{2}, 9-\mathrm{CH}_{4}, 10-\mathrm{C}_{2} \mathrm{H}_{2}$

$V_{\%}$ values obtained according to equations (4) and (6) $-V_{\%(4,6)}$ are very close to $V_{\%}$ values obtained from experimental data [1]. For the investigated materials, we obtained the following $V_{\%(4,6)} / V_{\%(\exp )}$ values:

\section{$\mathrm{C}_{6} \mathrm{H}_{14}-2,40 / 2,5 ; \quad \mathrm{C}_{5} \mathrm{H}_{12}-2,84 / 3,0 ; \quad \mathrm{C}_{6} \mathrm{H}_{6}-3,02 / 3,0$; $\left(\mathrm{C}_{2} \mathrm{H}_{5}\right)_{2} \mathrm{O}-4,67 / 4,5 ; \mathrm{C}_{3} \mathrm{H}_{6}-4,95 / 4,7 ; \quad\left(\mathrm{CH}_{3}\right)_{2} \mathrm{CO}-6,15 / 6,2$; $\mathrm{C}_{2} \mathrm{H}_{4}-7,26 / 7,0 ; \quad \mathrm{CS}_{2}-8,46 / 8,5 ; \quad \mathrm{CH}_{4}-10,56 / 10,5$; $\mathrm{C}_{2} \mathrm{H}_{2}-8,6 / 10$.}

The correlation coefficient reaches even 0,9998 (Fig 2).

So equations (4) and (6) give us a proper dependency of combustible material amount in mixtures with air at maximum flame propagation rates on combustible material composition.

$V_{\%}$ values for $\mathrm{C}_{\mathrm{n}} \mathrm{H}_{2 \mathrm{n}+2}$ hydrocarbon series $\left(\mathrm{CH}_{4}\right.$, $\left.\mathrm{C}_{2} \mathrm{H}_{6}, \ldots\right)$ can be also found also by using equation (7), which is an analogy of equation (2):

$$
V_{\%}=33,3 /\left(1+2,15 n_{C}\right), \%,
$$

where $n_{C}$ - number of $\mathrm{C}$ atoms in $\mathrm{C}_{\mathrm{n}} \mathrm{H}_{2 \mathrm{n}+2}$ series hydrocarbon formula.

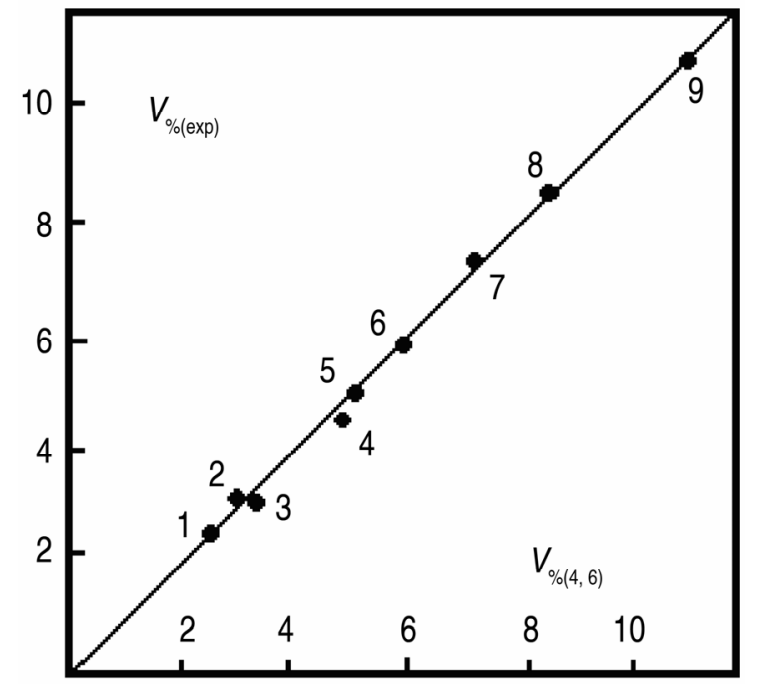

Fig 2. Correlation between $V_{\%}$ values, found experimentally (from [1]) $-V_{\%(\exp )}$ and values obtained from equations (4) and (6) $-V_{\%(4,6)}$. Material numbers are the same as in Fig 1

\subsection{Calculation results of combustible material and air mixture composition at maximum flame propaga- tion rate}

The information presented below include the most important organic combustible materials, which are used in plants, factories, construction sites as well as in shop warehouses, power utilities technical, transport, trade network as well as in households, $V_{\%}$ values, which we obtained according to (4) and (6) equations are given. The following is given in the list: material's name, brutto formula and in brackets - physical state at room, temperature ( $\mathrm{s}$ - solid, 1 - liquid, $\mathrm{g}$ - gaseous; in case of solid or liquid materials, it boiling temperature, ${ }^{\circ} \mathrm{C} ; V_{\%}$ value):

- $\quad$ Hydrocarbons

1. Alkanes, $\mathrm{C}_{\mathrm{n}} \mathrm{H}_{2 \mathrm{n}+2}$ :

methane $\mathrm{CH}_{4}$ (g) 10,56; ethane $\mathrm{C}_{2} \mathrm{H}_{6}$ (g) 6,28; propane $\mathrm{C}_{3} \mathrm{H}_{8}$ (g) 4,48; butane $\mathrm{C}_{4} \mathrm{H}_{10}$ (g) 3,47; pentane $\mathrm{C}_{5} \mathrm{H}_{12}$ (l, 36) 2,84; hexane $\mathrm{C}_{6} \mathrm{H}_{14}(1,69) 2,40$; heptane $\mathrm{C}_{7} \mathrm{H}_{16}(1,98)$ 2,08; octane $\mathrm{C}_{8} \mathrm{H}_{18}(1,125) 1,83$.

2. Alkenes, $\mathrm{C}_{\mathrm{n}} \mathrm{H}_{2 \mathrm{n}}$ :

ethene (ethylene) $\mathrm{C}_{2} \mathrm{H}_{4}$ (g) 7,26; propene (propylene) $\mathrm{C}_{3} \mathrm{H}_{6}$ (g) 4,95; butene (butylene) $\mathrm{C}_{4} \mathrm{H}_{8}$ (g) 3,76.

3. Alkines, $\mathrm{C}_{\mathrm{n}} \mathrm{H}_{2 \mathrm{n}-2}$ : etine (acetylene) $\mathrm{C}_{2} \mathrm{H}_{2}$ (g) 8,60.

4. Dienes (diolefins), $\mathrm{C}_{\mathrm{n}} \mathrm{H}_{2 \mathrm{n}-2}$ : 1,3-butadiene $\mathrm{C}_{4} \mathrm{H}_{6}(\mathrm{~g})$ 4,08; isoprene $\mathrm{C}_{5} \mathrm{H}_{8}(1,34)$ 3,23.

5. Cycloalkanes (cyclanes), $\mathrm{C}_{\mathrm{n}} \mathrm{H}_{2 \mathrm{n}}$ : cyclopropane $\mathrm{C}_{3} \mathrm{H}_{6}(\mathrm{~g}) 4,95$; cyclobutane $\mathrm{C}_{4} \mathrm{H}_{8}(\mathrm{l}, 13)$ 3,76 .

6. Cycloalkenes (cyclenes), $\mathrm{C}_{\mathrm{n}} \mathrm{H}_{2 \mathrm{n}-2}$ : cyclopropene $\mathrm{C}_{3} \mathrm{H}_{4}$ (g) 5,54.

7. Aromatic hydrocarbons (arenes):

1) $\mathrm{C}_{\mathrm{n}} \mathrm{H}_{2 \mathrm{n}-6}$ : benzene $\mathrm{C}_{6} \mathrm{H}_{6} \quad(1,80) \quad 3,02$; toluene $\mathrm{C}_{6} \mathrm{H}_{5} \mathrm{CH}_{3}(\mathrm{l}, 111)$ 2,53; o-ksilene $\mathrm{C}_{6} \mathrm{H}_{4}\left(\mathrm{CH}_{3}\right)_{2}(1,144)$ 2,18 ; 


$$
\text { 2) } \mathrm{C}_{\mathrm{n}} \mathrm{H}_{2 \mathrm{n}-8} \text { : styrene } \mathrm{C}_{6} \mathrm{H}_{5} \mathrm{CH}=\mathrm{CH}_{2}(1,145) 2,28 \text {. }
$$

- Alcohols

1. Saturated monohydroxy alcohols, $\mathrm{C}_{\mathrm{n}} \mathrm{H}_{2 \mathrm{n}+1} \mathrm{OH}$ : methyl (methanol) $\mathrm{CH}_{3} \mathrm{OH}(1,65)$ 14,84; ethyl (ethanol) $\mathrm{C}_{2} \mathrm{H}_{5} \mathrm{OH}(1,79) 8,46$; propyl (1-propanol) $\mathrm{C}_{3} \mathrm{H}_{7} \mathrm{OH}$ (1, 97) 6,15; butyl (1-butanol) $\mathrm{C}_{4} \mathrm{H}_{9} \mathrm{OH}(1,118)$ 4,96; amyl (1-pentanol) $\mathrm{C}_{5} \mathrm{H}_{11} \mathrm{OH}(1,138) 4,22$.

2. Alicyclo alcohols, $\mathrm{C}_{\mathrm{n}} \mathrm{H}_{2 \mathrm{n}-1} \mathrm{OH}$ :

cyclobutanol $\mathrm{C}_{4} \mathrm{H}_{7} \mathrm{OH}(1,123) 5,28$;

cyclopentanol $\mathrm{C}_{5} \mathrm{H}_{9} \mathrm{OH}(1,141) 4,43$; cyclohexanol

$\mathrm{C}_{6} \mathrm{H}_{11} \mathrm{OH}(1,161) 3,88$.

3. Aromatic alcohols, $\mathrm{C}_{\mathrm{n}} \mathrm{H}_{2 \mathrm{n}-7} \mathrm{OH}$ :

benzyl alcohol $\mathrm{C}_{6} \mathrm{H}_{5} \mathrm{CH}_{2} \mathrm{OH}(1,205) 3,88$.

4. Bihydroxy alcohols, $\mathrm{C}_{\mathrm{n}} \mathrm{H}_{2 \mathrm{n}}(\mathrm{OH})_{2}$ : ethylene glycol (etandiol) $\mathrm{C}_{2} \mathrm{H}_{4}(\mathrm{OH})_{2}(1,198) 9,80$.

5. Trihydroxy alcohols, $\mathrm{C}_{\mathrm{n}} \mathrm{H}_{2 \mathrm{n}-1}(\mathrm{OH})_{3}$ : glycerine (propantriol) $\mathrm{C}_{3} \mathrm{H}_{5}(\mathrm{OH})_{3}(1,290) 7,48$.

- Ethers

diethyl ether $\left(\mathrm{C}_{2} \mathrm{H}_{5}\right)_{2} \mathrm{O}(1,35) 4,96$; dioxane $\mathrm{C}_{4} \mathrm{H}_{8} \mathrm{O}_{2}$ $(1,102) 5,68$.

- Aldehydes formaldehyde $\mathrm{HCHO} \quad(\mathrm{g}) \quad 20,47$; acetaldehyde $\mathrm{CH}_{3} \mathrm{CHO}(1,20) 9,80$.

- $\underline{\text { Ketones }}$ acetone $\left(\mathrm{CH}_{3}\right)_{2} \mathrm{CO}(1,56) 6,74$.

- Carboxylic acids (carbonic acids):

formic (methane) acid $\mathrm{HCOOH}(1,101) 34,04$; acetic (ethane) acid $\mathrm{CH}_{3} \mathrm{COOH}(1,118) 11,76$; acrylic (propene) $\operatorname{acid} \mathrm{CH}_{2}=\mathrm{CHCOOH}(1,140) 8,46$.

Analysis of all the data shows that the more $\mathrm{C}$ atoms (as well as $\mathrm{H}$ atoms) in the compound molecules, the more oxygen (as well as air) there should be in a combustible mixture. As a result, the flammable gas volume (\%) in a gaseous mixture $V_{\%}$ is inversely proportional to $\mathrm{C}$ atom number (as well as to $n_{\mathrm{O}_{2}}$ ) in alkane molecules. All this is reflected in equation (2).

\subsection{Combustible material and air mixture composi- tion dependency on combustion enthalpy value}

We can logically think, that value $V_{\%}$ can correlate with combustible material combustion enthalpies (combustion heat) $\Delta H_{\text {comb }}$.

To evaluate this proposition below we compared some combustible organic compound experimental $V_{\%}$ values (\%) from [1] $-V_{\%(\exp )}$ and (as a fraction) $\Delta H_{c o m b}$ ( $\mathrm{kcal} / \mathrm{mol})$ values:

$\mathrm{C}_{6} \mathrm{H}_{14} \quad 2,5 / 1032 ; \quad \mathrm{C}_{5} \mathrm{H}_{12} \quad 3,0 / 845 ; \quad \mathrm{C}_{6} \mathrm{H}_{6} \quad 3,0 / 819$; $\left(\mathrm{C}_{2} \mathrm{H}_{5}\right)_{2} \mathrm{O}$ 4,5/652; $\mathrm{C}_{3} \mathrm{H}_{6}$ 4,7/522; $\left(\mathrm{CH}_{3}\right)_{2} \mathrm{CO}$ 6,2/427; $\mathrm{C}_{2} \mathrm{H}_{4} 7,0 / 302 ; \mathrm{CS}_{2} 8,5 / 264 ; \mathrm{C}_{2} \mathrm{H}_{2} 8,6 / 311 ; \mathrm{CH}_{4} 10,5 / 243$.

On the basis of these values we created a $V_{\%(\text { (еx) }}-$ $\Delta H_{\text {comb }}$ relationship (Fig 3).

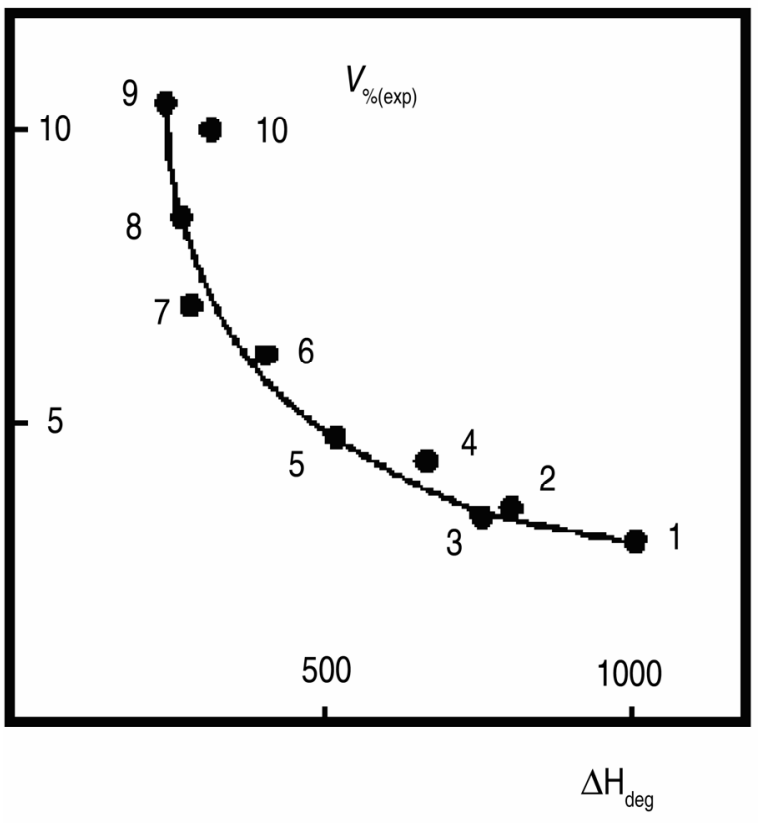

Fig 3. Relationship between experimental $V_{\%}$ values $V_{\%(\text { exp) }}$ and combustion enthalpies $\Delta H_{\text {comb }}(\mathrm{kcal} / \mathrm{mol})$. Material numbers are the same as in Figs 1 and 2; $10-$ $\mathrm{C}_{2} \mathrm{H}_{2}$

The given correlation has a product $V_{\%} \cdot \Delta H_{\text {comb }} \approx$ const meaning and could be expressed by the following equation:

$$
V_{\%} \cdot \Delta H_{\text {comb }}+30 \approx 2560,
$$

where $30-\mathrm{C}-\mathrm{H}$ as well as $\mathrm{C}-\mathrm{H}-\mathrm{O}$ type compounds combustion enthalpy high-temperature increase ( $\mathrm{kcal} / \mathrm{mol}), 2560$ - product of $V_{\%}\left(\Delta H_{\text {comb }}+30\right)$ value for mention e dtypes of compounds $(\mathrm{kcal} / \mathrm{mol})$.

From equation (8) we can find the final correlation:

$$
V_{\%} \approx 2560 /\left(\Delta H_{\text {comb }}+30\right)(\%) \text {. }
$$

Below we compared $V_{\%}$ values according to equation (9) $V_{\%(8)}$ with (as a fraction) experimental $V_{\%}$ values $V_{\%(\exp )}$ :

$\mathrm{C}_{6} \mathrm{H}_{14}$ 2,41/2,5; $\mathrm{C}_{5} \mathrm{H}_{12}$ 2,93/3,0; $\mathrm{C}_{6} \mathrm{H}_{6}$ 3,02/3,0; $\left(\mathrm{C}_{2} \mathrm{H}_{5}\right)_{2} \mathrm{O}$ $3,75 / 4,5 ; \quad \mathrm{C}_{3} \mathrm{H}_{6} \quad 4,64 / 4,7 ; \quad\left(\mathrm{CH}_{3}\right)_{2} \mathrm{CO} \quad 5,60 / 6,2 ; \quad \mathrm{C}_{2} \mathrm{H}_{4}$ $7,71 / 7,0 ; \mathrm{CS}_{2} 8,71 / 8,5 ; \mathrm{CH}_{4} 9,38 / 10,5 ; \mathrm{C}_{2} \mathrm{H}_{2}$ 7,51/10.

Relationship between $V_{\%}$ values obtained from equation (9) and experimental $V_{\%}$ values $-V_{\%(\exp )}$ is given in Fig 4 . As we can see, there is a very good correlation between these values (the correlation coefficient is equal to 0,9798 ).

This relationship can be explained by the fact that the larger the material combustion enthalpy, the lower the combustible material concentration in a combustible mixture. 


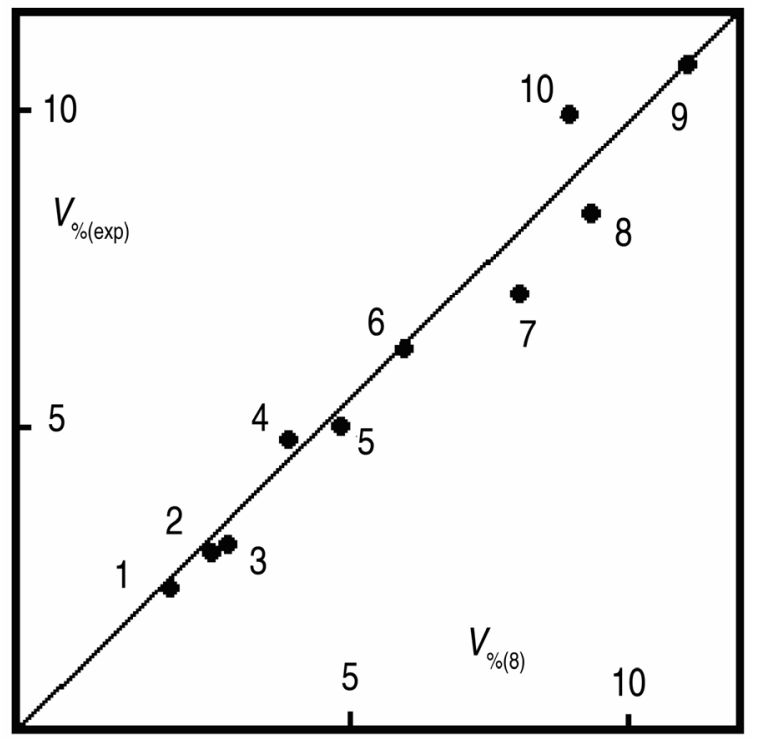

Fig 4. Correlation between $V_{\%}$ values obtained from equation (8) $-V_{\%(8)}$ and experimental $V_{\%}$ values $-V_{\%(\exp )}$

\section{Conclusions}

1. Equations were derived which described relationship between combustible material volume fractions, \% of this material and air mixture $\left(V_{\%}\right)$ on stoichiometric coefficient reaction values in equations $\left(n_{\mathrm{O}_{2}}\right)$ :

- for C-H type compounds

$$
V_{\%}=111 /\left(1+4,76 n_{\mathrm{O}_{2}}\right)(\%),
$$

- for C-O-H type compounds

$$
V_{\%}=111 /\left(1+4,76 n_{O_{2}}\right)+1,2(\%),
$$

where 4,76-coefficient inversely proportional to the amount of oxygen in the air by parts $(0,21)$.

2. $V_{\%}$ values for several tens of combustible organic materials were determined on the basis of these equations.

3. The knowledge of $V_{\%}$ values will allow to make apparent the most fire dangerous materials in households, production and other premises and allow to plan efficiently protection of human beings, animals as well as constructions and equipment against fires.

\section{References}

1. Горение. Большая советская энциклопедия, т. 12. Москва: БСЭ, 1952, с. 81-85.

2. Абурагимов, И. М.; Андросов, А. С. Процессы горения. Москва: ВИПТИС МВД СССР, 1984. 268 с.

3. Демидов, П. Г.; Шандыба, В. А.; Щеглов, П. П. Горение и свойства горючих веществ. Москва: Химия, 1982. $272 \mathrm{c}$.

4. LST 1324:1993 „Degimas ir medžiagu gaisrinis pavojingumas" (in Lithuanian).

5. Frank-Kaminski, D. A. Diffusion and heat exchange in chemical kinetics. Princetown University Press, 1995. $124 \mathrm{p}$.

6. Fizykochemia spalania i wybuchow. Warszawa: Szkola Glowna Sluzby Pozarniczej, 1996. 190 p.

7. Pofit-Szcepanska, M. Wybrane zagadnienia $\mathrm{z}$ chemini ogżolnej fizikochemii spalania i rozwoju pożarow. Krakow: Szkola aspirantow panstwowej straży pożarnej, 1994. 112 p.

8. Саушев, В. С. Пожарная безопасность хранения химических веществ. Москва: Стройиздат, 1982. $128 \mathrm{c}$.

9. Монахов, В. Т. Методы исследования пожарной опасности вещества. Москва: Химия, 1979. 352 с.

10. Mačiulaitis, R. Gaisro ir sprogimo pavojaus technologiniuose procesuose įvertinimo būdai. Vilnius: Technika, 1996. $64 \mathrm{p}$.

11. Карапетьянц, М. Х. Химическая термодинамика. Москва: Химия, 1975. 584 с.

12. Киреев, В. А. Методы практических расчетов в термодинамике химических реакций. Москва: Химия, 1970. $520 \mathrm{c}$.

13. Kazragis, A. Praktinè cheminė termodinamika. Vilnius: Technika, 1998. $90 \mathrm{p}$.

14. Lange's Handbook of chemistry. New York: McGrawHill Book Company, 1973. 1572 p.

15. Tabellenbuch Chemie. Leipzig: VEB Deuscher Verlag für Grundstoffindustrie, 1968. S. 488.

\section{DEGIŲJŲ MEDŽIAGŲ IR ORO MIŠINIŲ SUDĖTIS, LEMIANTI MAKSIMALŲ LIEPSNOS PLITIMO GREITI}

\section{A. Kazragis, A. Gailius}

\section{Santrauka}

Nagrinėjama labai svarbi gaisrinès saugos požiūriu degiujų dujinių medžiagų (arba jų garų, susidarančių degant kietosioms bei skystosioms degiosioms medžiagoms) tūrinès koncentracijos $V_{\%}$ dujų ir oro mišinyje priklausomybè nuo šių medžiagų sudèties, lemianti maksimalų linijinị liepsnos plitimo greitị.

Sudarytos šią priklausomybę nusakančios lygtys, kurios gali būti taikomos itin pavojingoms degiujų dujų tūrinèms koncentracijoms degiujų medžiagų ir oro mišinyje apskaičiuoti. Skaičiavimų rezultatai padeda nustatyti gaisrų kilimo atžvilgiu pavojingiausias medžiagas ir imtis priemonių pavojingų situacijų išvengti.

Prasminiai žodžiai: degiosios medžiagos, degiujų mišinių koncentracijos. 
СОСТАВ СМЕСЕЙ ГОРЮЧИХ ВЕЩЕСТВ И ВОЗДУХА, СООТВЕТСТВУЮЩИЙ МАКСИМАЛЬНОЙ СКОРОСТИ РАСПРОСТРАНЕНИЯ ПЛАМЕНИ

\section{А. Казрагис, А. Гайлюс}

Резюме

Рассмотрена важная в отношении пожароопасности зависимость содержания газообразных горючих газов (или паров, образовавшихся из жидких горючих жидкостей в условиях горения) в их смеси с воздухом при максимальной скорости распространения пламени от стехиометрического количества молекул кислорода в уравнении реакции горения.

Получены уравнения, связывающие упомянутые факторы. На основании этих уравнений рассчитаны наиболее опасные концентрации горючих смесей для ряда органических веществ. Знание этих концентраций позволит оценить степень опасности веществ на производственных, строительных и военных объектах.

Ключевые слова: горючие вещества, концентрации горючих смесей.

Algimantas KAZRAGIS. Dr Habil, Prof, Dept of Chemistry and Biochemistry, Vilnius Gediminas Technical University (VGTU).

Doctor Habil of Natural Sciences (chemistry), Lithuanian Academy of Sciences, 1990. Doctor of Chemical Sciences, Lithuanian Academy of Sciences, 1963. First degree in Chemical Process Engineering, Kaunas Polytechinc Institute (KPI), 1955. Professor (1993), Associate Professor (1966), senior lecturer (1968), lecturer (1963), VGTU (formerly VISI). Head of Dept of Building Materials (1995-1996), head of Dept of Chemistry and Biochemistry (1996-2001), VGTU. Membership: corresponding member of International Academy of Ecological and Life Protection Sciences (2004). Teaching: lectures in five subjects for bachelor and master students. Publications: author of 5 textbooks, co-author of several scientific publications, author of 150 research papers and 5 patents. Research interests: thermodynamics and kinetics of inorganic and building materials.

Albinas GAILIUS. Dr, Prof, Dept of Building Materials, Vilnius Gediminas Technical University (VGTU).

Phd of Technological Sciences (1968), Doctor of Technological Sciences (1963), Associate Professor (1972). First degree in Civil Engineering, Kaunas University of Technology (1963). Conferences: participant of over 70 international conferences. Teaching: lectures in three branches of science: Materials Science, Civil Engineering and Environmental Engineering. Publications: author and co-author of 12 textbooks, over 100 research papers. Research interests: materials science, building materials and structures. 